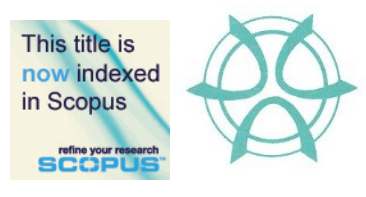

PLANNING MALAYSIA:

Journal of the Malaysian Institute of Planners

VOLUME 19 ISSUE 1 (2021), Page 89 - 101

\title{
SPATIAL DEMOGRAPHIC DATA FOR PLANNING AND RESEARCH
}

\author{
Tey Nai Peng', Rozita Talha ${ }^{2}$, Ezatul Nisha Abdul Rahman ${ }^{3}$, Muhamad Fadzil \\ Ismail $^{4}$
}

${ }^{I}$ Faculty of Economics and Administration

UNIVERSITY OF MALAYA

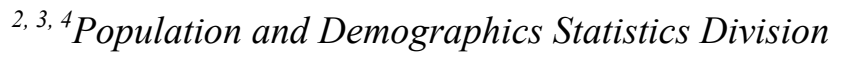

DEPARTMENT OF STATISTICS MALAYSIA

\begin{abstract}
In Malaysia, spatial demographic studies are lacking due to data paucity. This exploratory study illustrates the relevance of spatial demographic data for development and business planning at the local level. Data for this study came from Malaysian population censuses, vital statistics reports and social statistics bulletins. Bivariate analyses were performed to present some examples of the potential use of spatial demographic data for more target-oriented planning. Data show that the population in several densely populated districts continues to grow rapidly. Hence, development planning should aim to forestall the exacer-bation of the regional imbalance. Localities with high birth rate and rapid population ageing must be prepared to cope with the changing demographic scenario. The wide variations in pupil-teacher ratio across districts indicate the need for resource reallocation. The under-reporting of births and deaths in the remote areas may result in misallocation of health and educational resources. Comparisons of indictors from different data sources demonstrate data inconsistency and deficiency. This study aims to present a strong case for collecting and disseminating small area statistics to enhance spatial demographic research for socio-economic development, infrastructural, regional and business planning.
\end{abstract}

Keywords: Spatial demographic data, sub-national levels, state, district, births, older people

\footnotetext{
${ }^{1}$ Retired Associate Professor, University of Malaya. Email: teynp@um.edu.my
} 
Nai Peng Tey, Rozita Talha, Ezatul Nisha Abdul Rahim, Muhamad Fadzil Ismail

Spatial Demographic Data for Research and Planning

\section{INTRODUCTION}

The vast literature on the inter-relationships between population and development testifies the importance of population factors in development planning. The 2030 Development Agenda on Sustainable Development Goals calls for leaving no one behind and targeting those who are left furthest behind. It is crucial to have disaggregated data for small geographical areas and pockets of marginalised population for a more targeted service delivery, as well as allocation of resources to bring about a more balanced regional growth. For instance, the B40 income group must be indentified and located for the delivery of the financial assistance. Small area statistics are also essential for business planning by the private sector (Noordini Che'Man \& Harry Timmerman, 2016).

Data impacts development through better policy making and public service delivery, enhances research and facilitates the private sector to contribute to economic growth. Reliable and timely data allow policymakers, planners, administrators, companies and the public to make better, timely and more informed decisions, and enhance accountability. The public sector is increasingly using data to formulate, monitor and evaluate policies to improve public service delivery. Researchers use data to undertake empirical analysis to inform policy. The private sector uses data for product development, market analysis, and evidence-based decision-making or assessment (Ministry of Health, 2018; World Bank, 2017).

While the five-year development plans, the National Physical Plans and the National Urbanization Policy provide a framework for development planning at the national level, all the states have formulated and implemented the state structure plans or master plans to deal with the regional and local issues. All mega projects are also required to have a social impact assessment. All these master plans and assessments would require spatial demographic data.

There is a rather sizable literature on Malaysia's demographic dynamics at the national level (Arshat et al., 1988; Chander et al., 1977; Cheong \& Lim, 1982; Leete, 1996, 2007; Lim, 1983; National Population and Family Development Board, 2016, 2018; Saw, 2007; Sidhu \& Jones, 1981; Tey et al., $2015,2020)$. Although space is a crucial element in demographic studies and a good knowledge of spatial demography is crucial for planning (de Castro, 2007), demographic analysis at the sub-national levels is deficient due to data paucity. The few spatial demographic analyses reveal wide differentials in the demographic dynamics and socio-economic and health outcomes across the districts (Diah Intan 2020; Abd Majid, N et al,n 2019; Siti Uzairiah Mohd Tobi, 2018; Md Bohari, et al., 2019; Abdul Rashid, M. F., 2017; Hazrin, H., 2013; Masron, T., 2012; Abdul Rahman \& Zakaria, 2012; Azreena et al., 2016; Hutchinson, 2008; Ibrahim Ngah, 2010; Khalid Zanudin et al., 2019; Ling et al., 2014; Mohamad Fadhli Rashid et al., 2019; Nuzlinda \& Syerrina, 2012; Tey, Tan, \& Arshat, 1985). 
PLANNING MALAYSIA

Journal of the Malaysia Institute of Planners (2021)

In keeping with the increasing demand for small area statistics (SAS), the Department of Statistics Malaysia (DOSM) has been publishing SAS, such as the decennial population censuses, annual vital statistics, data bank, social statistics, wholesale and retail trade, as well as other statistics by state and district. DOSM initiated the publication of My Local Statistics in 2019. Despite these efforts, there is still a need to expand the collection and dissemination of SAS to enhance spatial demographic analysis. For planning purposes, the data must be disaggregated by gender, age and socio-economic characteristics.

This study is exploratory and illustrative to stimulate spatial demographic analysis and more effective use of demographic data for development planning and business planning. This study also aims to highlight the deficiency in spatial data so that measures can be taken to fill the gaps. It covers selected aspects of the population, including population density, population growth and distribution or concentration, fertility and mortality, pupilteacher ratio in the secondary school, and population ageing. The data for this study came from the published reports of the population censuses, vital statistics reports and state or district social statistics reports. Simple tabulations, scatterplots and maps were used to present the findings.

\section{FINDINGS}

\section{Population Density and Rate of Population Growth}

Malaysia has a population density of about 100 people per square kilometre in 2010, ranging from 19 people per square kilometre in Sarawak to 6,891 in the Federal Territory of Kuala Lumpur. In Peninsular Malaysia, besides Kuala Lumpur, Timur Laut and Petaling are the two most densely populated districts (with a population density of 4,330 and 3,012, respectively). On the other hand, Gua Musang, Jerantut, Lipis, and Ulu Perak have the lowest population density of around 13 to 17 people per square kilometre.

Between 2000 and 2015, the rate of population growth ranged from 1.2 per cent per annum in Perak to 2.6 per cent in Selangor. The variation in the rate of population growth was even more striking across the districts, ranging from -1.0 per cent in Jempol to a high percentage of 6 per cent in Sepang during the intercensal period from 2000 to 2010 . Figure 1 shows that a few densely populated districts have a high rate of population growth. The rapid growth will result in further population concentration and aggravation of regional inequality. 


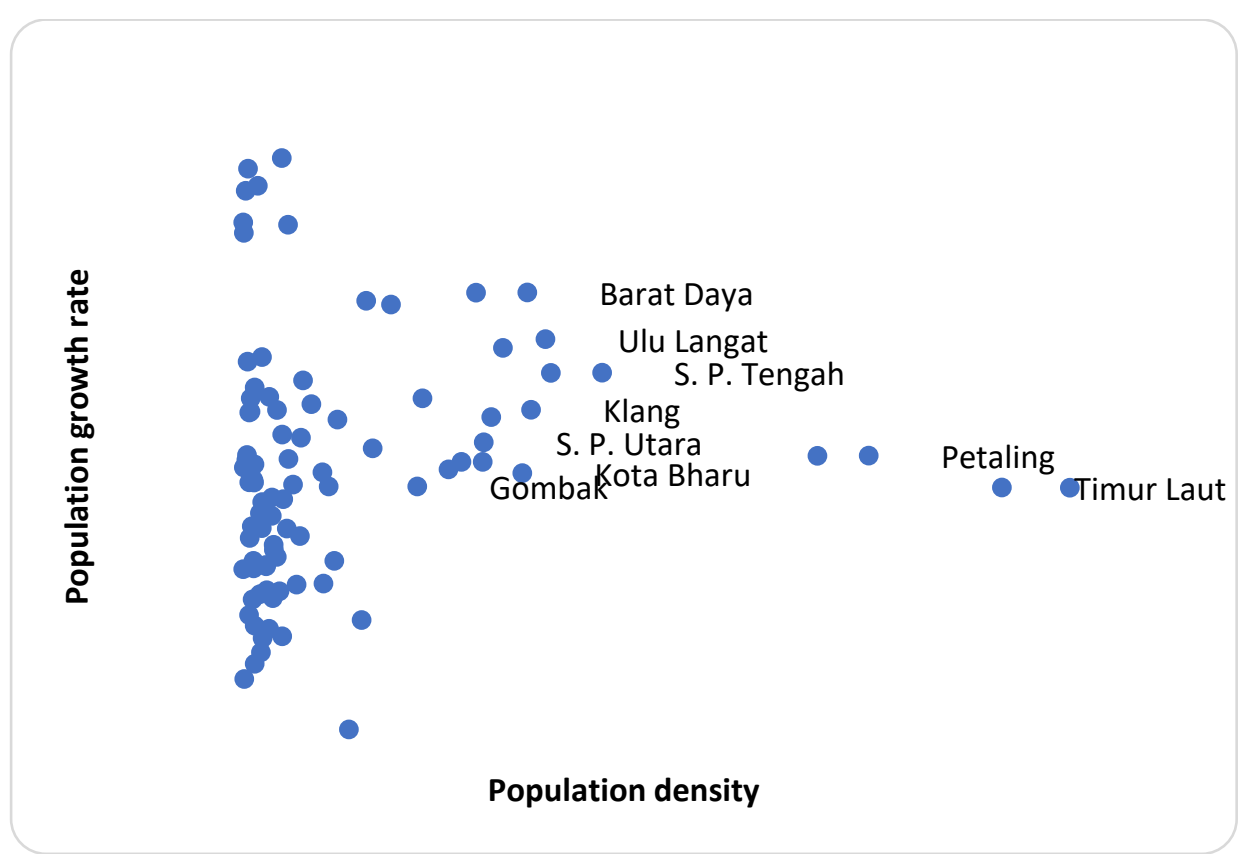

Figure 1: Population density and rate of population growth, by district Note: Excluding Wilayah Persekutuan Kuala Lumpur (population density 7,089 persons per square km, with an annual rate of population growth of $2.8 \%$ )

Source: DOSM (2011): Population Distribution by Local Authority Areas and Mukims, 2010; Population Censuses, 2000, 2010

The population of Petaling district increased almost five folds from 360 thousand in 1980 to 1.77 million in 2010, at a rate of 5.3 per cent per annum. Consequently, Petaling had overtaken Kuala Lumpur as the most populous district. The population of Johor Bahru increased more than three folds between 1980 and 2010, making it the third most populous district. Ulu Langat, which was the ninth most populous district in 1980, witnessed the most rapid population growth at 6.2 per cent per annum over this period, to leapfrog into the fourth place in 2010. With a population growth rate of 3.7 per cent per annum over the three decades, Klang remained the fifth most populous district in 2010. Even though Kinta remained the sixth most populous district in 2010, its population grew much slower than many other districts.

More than a third (34.4 per cent) of the national population now lives in the ten most populous districts: Petaling, Kuala Lumpur, Johore Bahru, Ulu Langat, Klang, Kinta, Gombak, Kuching, Seremban, and Timur Laut. The National Physical Plan projected a population of 10.37 million, 2.42 million, 2.40 million, and 1.38 million for Greater Kuala Lumpur (including Petaling Jaya), Georgetown, Johor Bahru, and Kuantan, respectively in 2020. The combined total population of 16.57 million in these four conurbations will make up about 70 per 
cent of the urban population or 60.4 per cent of the total population in Peninsular Malaysia (Federal Department of Town and Country Planning, 2010).

There are several reasons for the phenomenal population growth in these districts. Petaling and the other four districts in the Klang Valley have attracted migrants from all over the country to take up jobs in administration, commercial, financial, industrial, educational, and service sectors. The various economic policies and programmes require relocation to the cities, leading to dramatic population redistribution over the last few decades.

Eight districts had experienced depopulation between 1970 and 2010. These districts included Sabak Bernam, Temerloh, Julau, Betong, Dalat, Sri Aman, and Hilir Perak. Sabak Bernam and Temerloh had a deficit of more than 50,000 people between 1980 and 2010 at a rate of -2.7 per cent and -1.0 per cent per annum, respectively. During the 1991-2000 inter-censal period, the population of Sabah Bernam decreased 6.6 per cent per annum, while that of Temerloh decreased 3.6 per cent annually. There was a reversal in Temerloh during the ensuing decade, as the population grew at 1.7 per cent per annum. Julat and Betong (both in Sarawak), had a different demographic trend. The population of Julat decreased by half between 2000 and 2010. On the other hand, the population of Betong has been increasing since 1991 after registering a sharp decline between 1980 and 1991.

\section{Births and Deaths}

The fertiltiy rate and mortality rate in Malaysia have fallen to a low level. The total fertility rate has fallen below the replacement level since 2012. NonBumiputeras are now having ultra-low fertility of about 1.2 children per woman. Nevertheless, wide variations in the fertility and mortality rates persist across regions and sub-groups of the population. The government agencies require information on the number of births in small geographical areas for short-term and medium-term planning to provide health care and educational services and facilities, and other infrastructures. Information on the number of births and children is also essential for business planning, such as infant and child products, childcare centres, kindergartens, and other services.

The crude birth rate (CBR) ranged from 4.5 per thousand population in Kinabatangan to 26.4 in Kuala Terengganu, while the crude death rate (CDR) ranged from 1.0 per thousand population in Kinabatangan to 9.1 in Kanowit (see Tables 1 and 2). Four of the six districts with the highest CBR are in Terengganu. Kinabatangan has registered the lowest CBR and CDR in the country. The extremely low CBR and CDR in Kinabatangan is likely due to under-registration, as the district has a very high proportion of non-citizens.

The proportion of the older population aged 60 and above is directly related to $\mathrm{CDR}$ at the district level. The strong positive association between these two variables indicates that CDR is affected by the population's age structure. 
Nai Peng Tey, Rozita Talha, Ezatul Nisha Abdul Rahim, Muhamad Fadzil Ismail

Spatial Demographic Data for Research and Planning

The ultra-low CDR in some districts could be due to under-registration or misreporting, especially in the remote areas in Sabah and Sarawak. There is a need for an evaluation of the extent of under-reporting in these remote areas.

The child-woman ratio for each district was estimated using data from the population censuses. Assuming that the child-woman ratio is a fairly good indicator of fertility, there is evidence of under-and over-reporting of births in some districts. Attention should be given to districts and small areas where the birth rate is incredibly low or high. Nonetheless, the extremely low fertility and mortality rates in these districts may be due to misclassification of births and deaths by the place of registration rather than the usual place of residence.

Table 1: Districts with the highest and lowest crude birth rate, 2017

\begin{tabular}{|l|l|c|c|c|c|}
\hline & & CBR & Rank & Child-women ratio & Rank \\
\hline Highest & Putrajaya & 28.8 & 1 & 454 & 22 \\
\hline & Kuala Terengganu & 26.4 & 2 & 335 & 97 \\
\hline & Marang & 26.0 & 3 & 402 & 48 \\
\hline & Julau & 24.7 & 4 & 360 & 73 \\
\hline & Besut & 24.5 & 5 & 470 & 15 \\
\hline & Setiu & 24.0 & 6 & 567 & 3 \\
\hline & Tumpat & 22.9 & 7 & 351 & 81 \\
\hline & Pasir Puteh & 22.7 & 8 & 412 & 41 \\
\hline & Pasir Mas & 21.7 & 9 & 346 & 86 \\
\hline & Tanah Merah & 21.7 & 10 & 436 & 29 \\
\hline & Kinabatangan & 4.5 & 144 & 316 & 115 \\
\hline & Putatan & 5.6 & 143 & 470 & 16 \\
\hline & Pakan & 6.4 & 142 & 170 & 140 \\
\hline & Bagan Datuk & 8.3 & 141 & 271 & 130 \\
\hline & Timur Laut & 8.4 & 140 & 213 & 138 \\
\hline & Belaga & 8.6 & 139 & 399 & 49 \\
\hline & Kampar & 9.0 & 138 & 182 & 139 \\
\hline & Tongod & 9.2 & 137 & 166 & 142 \\
\hline & Beluran & 10.2 & 136 & 422 & 36 \\
\hline & Sandakan & 10.4 & 135 & 218 & 137 \\
\hline & & & Source: DOSM: Vital Statistics Report, 2018
\end{tabular}

Table 2: Districts with the highest and lowest crude death rate, 2017

\begin{tabular}{|l|l|c|c|c|}
\hline & & CDR & \% aged 65+ & Median age \\
\hline Highest & Kanowit & 9.1 & 15.6 & 30 \\
\hline & Sabak Bernam & 8.8 & 11.9 & 26 \\
\hline & Kuala Pilah & 8.7 & 14.5 & 30 \\
\hline & Pendang & 8.7 & 12.6 & 27 \\
\hline & Dalat & 8.6 & 12.6 & 27 \\
\hline & Kuala Kangsar & 8.5 & 14.2 & 28 \\
\hline
\end{tabular}


PLANNING MALAYSIA

Journal of the Malaysia Institute of Planners (2021)

\begin{tabular}{|l|l|c|c|c|}
\hline & Rembau & 8.4 & 12.8 & 29 \\
\hline & Jelebu & 8.3 & 13.8 & 29 \\
\hline & Baling & 7.9 & 10.8 & 24 \\
\hline & Kampar & 7.8 & 14.5 & 30 \\
\hline Lowest & Kinabatangan & 1.0 & 1.3 & 23 \\
\hline & Samarahan & 2.1 & 5.0 & 22 \\
\hline & Kunak & 2.1 & 2.9 & 24 \\
\hline & Belaga & 2.4 & 6.3 & 24 \\
\hline & Tongod & 2.4 & 3.3 & 18 \\
\hline & Labuan & 2.5 & 4.0 & 25 \\
\hline & Bintulu & 2.6 & 4.7 & 24 \\
\hline & Beluran & 2.6 & 3.0 & 21 \\
\hline & Lahad Datu & 2.6 & 2.9 & 27 \\
\hline & Putrajaya & 2.6 & 1.4 & 25 \\
\hline
\end{tabular}

While the rates are commonly used in demographic analyses, the actual numbers may be more relevant for planning purposes. Educational planners need to know the number of school-going children to plan the human resources and school facilities to cater to new school entrants as newborns reach the schoolgoing age. The vital statistics report depicts that a large number of births in some districts. Petaling registered the largest number of births at 30,044, followed by Johor Bahru, Kuala Lumpur, Ulu Langat, and Klang (see Table 3).

Table 3: Ten districts with the highest number of births, 2017

\begin{tabular}{|l|c|c|c|c|c|}
\hline Districts & Number & CBR & Districts & Number & CBR \\
\hline Malaysia & 508685 & 15.9 & Gombak & 14035 & 17.5 \\
\hline Petaling & 30044 & 14.2 & Kota Bharu & 12316 & 21.0 \\
\hline Johor Bahru & 25750 & 16.5 & Kinta & 10297 & 12.5 \\
\hline Kuala Lumpur & 24732 & 13.8 & Seremban & 9616 & 15.7 \\
\hline Ulu Langat & 21684 & 16.1 & Kuantan & 9128 & 17.7 \\
\hline Klang & 16574 & 16.6 & \multicolumn{5}{|c|}{ Source: DOSM: Vital Statistics Report, 2018 }
\end{tabular}

\section{Pupil-teacher ratio}

The pupil-teacher ratio is an indicator of the distribution of human resources in the education sector. This section uses the pupil-teacher ratio in secondary schools for illustrative purposes. In 2013, the pupil-teacher ratio in secondary school ranged from 9.7 in Putrajaya to 15.1 in Selangor. The spatial differential in the pupil-teacher ratio was even wider across districts, ranging from 7.4 in Maran to around 16 in Klang and Gombak, Ulu Langat and Bau (see Table 4). Districts with high population density and rapid population growth tended to have a higher pupil-teacher ratio. The large number of births in Klang, Gombak and 
Nai Peng Tey, Rozita Talha, Ezatul Nisha Abdul Rahim, Muhamad Fadzil Ismail

Spatial Demographic Data for Research and Planning

Ulu Langat would strain the educational facilities. Hence, more teachers are required in states or districts with a high pupil-teacher ratio to achieve the standard of 10:1 in developed countries.

Table 4: States or districts with the highest and lowest pupil-teacher ratio in secondary schools, 2013

\begin{tabular}{|c|c|c|c|c|}
\hline & & Highest & & Lowest \\
\hline \multirow[t]{5}{*}{ State } & Selangor & 15.1 & Putrajaya & 9.7 \\
\hline & Sabah & 13.7 & Labuan & 10.5 \\
\hline & Pulau Pinang & 13.6 & Perlis & 11 \\
\hline & Sarawak & 13.6 & Pahang & 11.2 \\
\hline & Kedah & 13.3 & Terengganu & 11.8 \\
\hline \multirow[t]{5}{*}{ District } & Klang & 16.1 & Maran & 7.4 \\
\hline & Gombak & 16.0 & Putrajaya & 9.7 \\
\hline & Ulu Langat & 16.0 & Beaufort & 9.9 \\
\hline & Bau & 15.6 & Port Dickson & 10.1 \\
\hline & Patatan & 15.3 & Kuala Pilah & 10.1 \\
\hline
\end{tabular}

Note: More recent data on pupil-teacher ratio are not available.

\section{Population Ageing}

Consequent to the continuing fertility decline and gain in life expectancy, the Malaysian population is ageing rapidly. Malaysia will become an ageing nation in 2030 when 15 per cent of the population will be aged 60 and over. In 2010, two districts and 98 mukims had an aging population (see Figure 2). Based on the population projection, the number of districts and mukims with an ageing population has probably increased to about 12 and more than 200, respectively, today. 


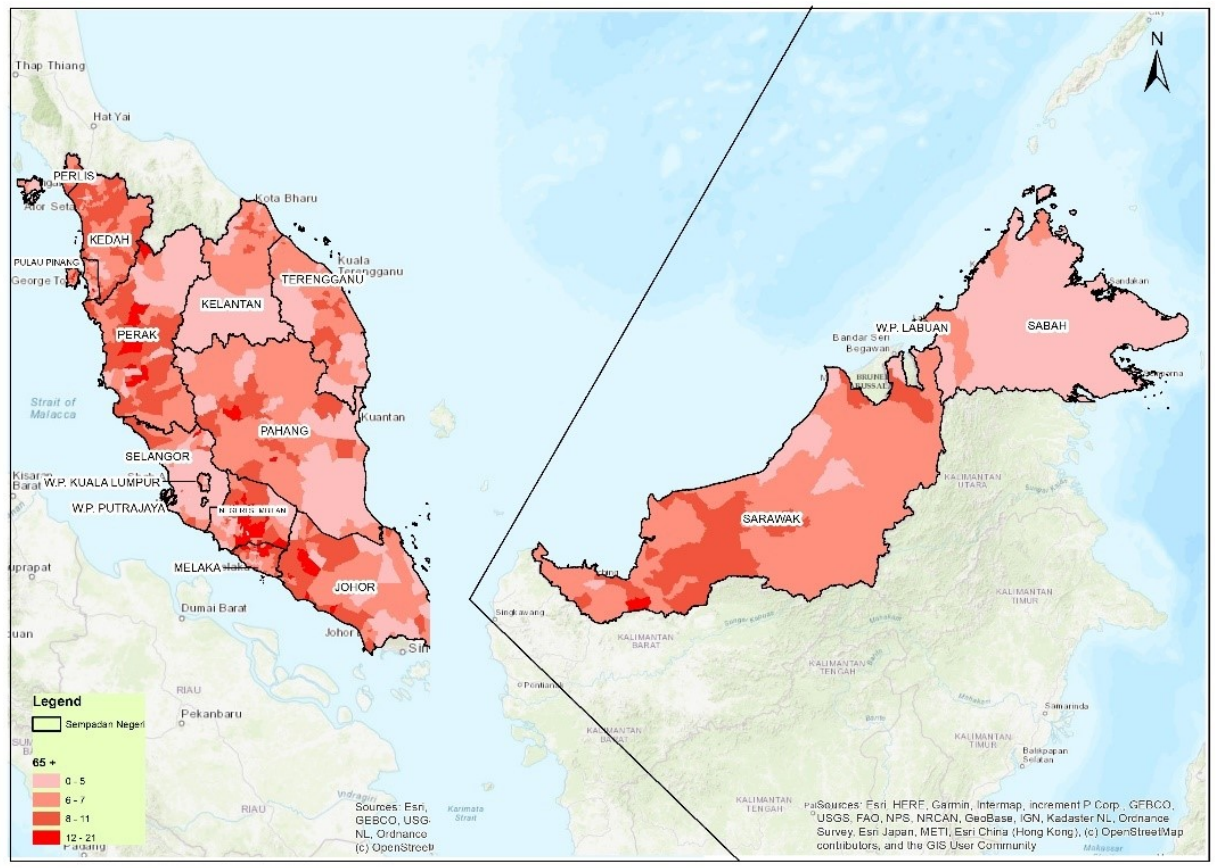

Figure 2: Map on population ageing (per cent aged 65 and above) Source: DOSM: Population and Housing Census, 2010

In 2010, 19 mukims had more than 10,000 older people, ranging from 10,617 in Batu to 50,288 in Ulu Kinta. Petaling registered the most rapid rise in the number of older adults. In most of these mukims, the older population had increased more than six per cent per annum, resulting in the doubling of the older population between 2000 and 2010 (see Table 5).

Out-migration of the youths has exacerbated population ageing in the less developed areas. Geographic information on the distribution of older people and their profiles is crucial for providing goods and services and public amenities to those in need. It is also imperative to provide older people with opportunities to continue their active engagement in society.

Table 5: Mukim with at least 10,000 people aged 65 and above in 2010 and growth between 2000 and 2010

\begin{tabular}{|l|c|c|c|c|}
\hline & $\mathbf{2 0 0 0}$ & $\mathbf{2 0 1 0}$ & $\begin{array}{c}\text { Annual rate } \\
\text { of growth }\end{array}$ & $\begin{array}{c}\text { Percentage } \\
\text { change }\end{array}$ \\
\hline Plentong & 6607 & 15,562 & 8.6 & 235.5 \\
\hline Pulai & 4617 & 11,704 & 9.3 & 253.5 \\
\hline Tebrau & 4272 & 10,725 & 9.2 & 251.1 \\
\hline Kluang & 5636 & 10,733 & 6.4 & 190.4 \\
\hline
\end{tabular}


Nai Peng Tey, Rozita Talha, Ezatul Nisha Abdul Rahim, Muhamad Fadzil Ismail

Spatial Demographic Data for Research and Planning

\begin{tabular}{|l|c|c|c|c|}
\hline Kuala Kuantan & 6305 & 13,531 & 7.6 & 214.6 \\
\hline Ulu Kinta & 28735 & 50,288 & 5.6 & 175.0 \\
\hline Georgetown & 14607 & 19,083 & 2.7 & 130.6 \\
\hline Paya Terubong) & 7822 & 14,833 & 6.4 & 189.6 \\
\hline Batu (Selangor) & 5584 & 10,617 & 6.4 & 190.1 \\
\hline Klang & 10388 & 19,963 & 6.5 & 192.2 \\
\hline Damansara & 8172 & 18,078 & 7.9 & 221.2 \\
\hline Petaling (Selangor) & 6434 & 17,871 & 10.2 & 277.8 \\
\hline Sungai Buloh & 8080 & 19,086 & 8.6 & 236.2 \\
\hline Ampang & 7605 & 12,814 & 5.2 & 168.5 \\
\hline Bandar KL & 8978 & 10,728 & 1.8 & 119.5 \\
\hline Batu (Wilayah) & 8587 & 17,133 & 6.9 & 199.5 \\
\hline Kuala Lumpur & 10002 & 18,918 & 6.4 & 189.1 \\
\hline Petaling (Wilayah) & 6690 & 13,483 & 7.0 & 201.5 \\
\hline Setapak & 6118 & 11,081 & 5.9 & 181.1 \\
\hline
\end{tabular}

Source: DOSM (2001, 2011): Population Distribution by Local Authority Areas and Mukims, Population

\section{DISCUSSION AND CONCLUSION}

This study used spatial data to demonstrate the unbalanced population distribution across regions, and portray the potential use of demographic data for planning purposes. The study has also highlighted demographic outcomes that warrant policy intervention. Additionally, it has raised some data reliability issues which require remedial actions to improve the registration and reporting systems. For instance, the under-reporting of births in a number of rural districts may have serious consequences such as resource misallocation and deprivation of services to those affected.

Population mobility and redistribution generally result in more efficient utilisation of human resources by moving surplus labour from one region to another region, in which there is a labour shortage. However, these processes also aggravate regional inequality. In its efforts to bring about a more balanced regional development, the Malaysian government has developed five development corridors and implemented other strategies. As the population continues to gravitate towards the central region, it appears that these development corridors have thus far been ineffective in population redistribution. Therefore, there is a need to find more effective ways to redistribute the population and improve the management of the cities. Detailed disaggregated socio-demographic data should be collected and analyzed for the formulation, implementation and evaluation of the state master plans, the National Physical Plans and the social impact assessment of mega projects.

While the fertility level in Malaysia has fallen below the replacement level, high fertility persists in certain localities, in which family planning practice is at a low level, and the unmet need for contraception is high. These localities 
PLANNING MALAYSIA

Journal of the Malaysia Institute of Planners (2021)

require more family planning efforts to provide couples with the necessary information and service to exercise their reproductive rights and plan their family size. A better understanding of the reasons for the higher mortality rate in some groups and localities can lead to measures to reduce the high death rate for these groups.

An in-depth analysis of the spatial distribution of the target groups is required for the allocation of resources to meet the needs of specific target groups, such as school-going children, the poor and the elderly. Multivariate analyses are needed to determine the covariates and confounding factors.

As stated at the outset, the purpose of this study is to present a case to the Department of Statistics Malaysia, as the central agency for official statistics to improve the collection, analysis and dissemination of spatial demographic data. The 2020 population census provides an excellent opportunity to fill the data gaps to develop SDG indicators to target the under-served and the needy to achieve the goal of "leaving no one behind."

\section{LIMITATIONS}

This study is exploratory, and it is meant to be illustrative of the relevance of spatial demographic data for planning in the public and private sectors. Some data are somewhat out-dated and are not sufficiently disaggregated for planning purposes. There are only a few readily available indicators. Data limitation precludes multi-layered analysis and analysis for smaller areas needed to improve the provision of targeted service and assistance.

\section{REFERENCES}

Abd Majid, N., Muhamad Nazi, N., \& Mohamed, A. F. (2019). Distribution and Spatial Pattern Analysis on Dengue Cases in Seremban District, Negeri Sembilan, Malaysia. Sustainability, 11(3572), 1-14.

Abdul Rahman, N., \& Zakaria, S. (2012). The household-based socio-economic index for every district in Peninsular Malaysia. International Scholarly and Scientific Research \& Innovation, 6(10), 1389-1395.

Abdul Rashid, M. F. (2017). Characteristics, Trends and Spatial Distribution of Urban Migration in Malaysia: A Case Study of the Klang Valley Region. UPLanD Journal of Urban Planning, Landscape \& environmental Design, 2(2), 107-127.

Arshat, H., Tan, B. A., Tey, N. P., \& Subbiah, M. (1988). Marriage and family formation in Peninsular Malaysia: Analytic report on the 1984/85 Malaysian population and family survey. Kuala Lumpur.

Azreena, C. A., Azreena, E., Arinah, W. D. S., Ezy Eriyani, N., Fairuz Nadiah, N., Gunenthira Rao, S., Muhammad Adil, Z. A., Muhamad Hanafiah Juni, \& Minhat, H. S. (2016). District Health Management Cycle in Malaysia. International Journal of Public Health and Clinical Sciences. 3(2), 16-30.

Chander, R., Palan, V. T., Aziz, N. L., \& Tan, B. A. (1977). Malaysian fertility and family survey: First country report. Kuala Lumpur. 
Nai Peng Tey, Rozita Talha, Ezatul Nisha Abdul Rahim, Muhamad Fadzil Ismail

Spatial Demographic Data for Research and Planning

Cheong, K. C., \& Lim, L. L. (1982). Demographic impact on socio-economic development: The Malaysian experience. Monograph No. 29. Development Studies Centre, Australian National University, Canberra.

de Castro, M. C. (2007). Spatial demography: An opportunity to improve policy making at diverse decision levels. Population Research and Policy Review, 26(5-6), $477-$ 509.

Diah Intan, Kusumo Dewi, Anita Ratnasari Rakhmatulloh, Diva Amadea (2020). Indicators of open space quality for children in high density settlements, Planning Malaysia, Vol. 18(1). pp 172-180

Department of Statistics Malaysia (DOSM) (2001): Population distribution by local authority areas and mukims, 2000; population censuses, 2000. Putrajaya.

Department of Statistics Malaysia (DOSM) (2010): Population censuses. Putrajaya.

Department of Statistics Malaysia (DOSM) (2011): Population distribution by local authority areas and mukims, 2010; Population censuses, 2010. Putrajaya.

Department of Statistics Malaysia (DOSM) (2010): Population censuses. Putrajaya.

Department of Statistics Malaysia (DOSM) (2013). State/district social statistics, Malaysia. Putrajaya.

Department of Statistics Malaysia (DOSM) (2018). Vital statistics Malaysia, 2018. Putrajaya.

Federal Department of Town and Country Planning. (2010). National Physical Plan-2. Putrajaya.

Hazrin, H., Fadhli, Y., Tahir, A., Safurah, J., Kamaliah, M. N., \& Noraini, M. Y. (2013). Spatial Patterns of Health Clinic in Malaysia. Health, 5(12), 2104-2109.

Hugo, G. (2011). Migration and Development in Malaysia: An Emigration Perspective. Asian Population Studies, 7(3), 219-242.

Hutchinson, F. E. (2008). "Developmental" states and economic growth at the sub-national level: The case of Penang. Southeast Asian Affairs 2008, 223-244.

Ibrahim Ngah (2010). Overview of regional development in Malaysia. Paper presented at International Conference on Regional Development: Vulnerability, Resilience and Sustainability, Universitas Diponegoro, Semarang

Khalid Zanudin, Ibrahim Ngah, \& Siti Hajar Misnan (2019). Limitations on community participation in planning decision-making in Peninsular Malaysia: A review of recent studies. International Review for Spatial Planning and Sustainable Development, 7(4), 131-147.

Leete, R. (1996). Malaysia's demographic transition: Rapid development: culture, and politics. Kuala Lumpur: Oxford University Press.

Leete, R. (2007). Malaysia: From kampung to Twin Towers, 50 years of economic and social development. Shah Alam: Oxford Fajar Sdn. Bhd.

Lim, L. L. (1983). Population and development: Theory and empirical evidence, the Malaysian case. Petaling Jaya: International Book Service.

Ling, C. Y., Gruebner, O., Kramer, A., \& Lakes, T. (2014). Spatio-temporal patterns of dengue in Malaysia: Combining address and sub-district level. Geospat Health, 9(1), 131-140.

Masron, T., Yaakob, U., Mohd Ayob, N., \& Mokhtar, A. S. (2012). Population and Spatial Distribution of Urbanisation in Peninsular Malaysia 1957 - 2000. Geografia : Malaysian Journal of Society and Space, 8(2), 20-29. 
Md Bohari, N. F., Kruger, E., John, J., \& Tennant, M. (2019). Analysis of Dental Services Distribution in Malaysia: A Geographic Information Systems - Based Approach. International Dental Journal, 69(3), 223-229.

Ministry of Health (2018). Size of key populations in Malaysia. Putrajaya: Estimates.

Mohamad Fadhli Rashid, Ibrahim Ngah, \& Siti Hajar Misnan (2019). Framework for economic performance of rural areas in Malaysia: A territorial approach, International Journal of Built Environment and Sustainability, 6(1-2), 1-6.

National Population and Family Development Board. (2016). Report on Key Findings: Fifth Malaysian Population and Family Survey (MPFS-5) 2014, Kuala Lumpur

National Population and Family Development Board (NPFDB) (2018). Situation analysis of population and family in Malaysia. Kuala Lumpur: NPFDB.

Noordini Che' Man \& Harry Timmerman, (2016) A discreet choice model for firm location decision. Planning Malaysia, Special Issue IV, 2016, 273-284

Nuzlinda, A. R., \& Syerrina Zakaria (2012). The household-based socio-economic index for every district in Peninsular Malaysia. World Academy of Science, Engineering and Technology, International Journal, 6(10),1389-1395.

Saw, S. H. (2007). The population of Malaysia. Singapore: Institute of Southeast Asian Studies (ISEAS) Publishing.

Sidhu, M. S., \& Jones, G. W. (1981). Population dynamics in a plural society: Peninsular Malaysia. Kuala Lumpur: University of Malaya Press.

Siti Uzairiah Mohd Tobi, Mohamad Syazli Fathi, \& Dilanthi Amaratunga (2018). Ageing in place framework as reference guide for housing in Malaysia landed property, Planning Malaysia, Vol 16(1). pp 130-143

Tey, N. P., Cheong, K. C., \& Rasiah, R. (2015). Revisiting Malaysia's Population and Development Nexus : The Past in Its Future. Kuala Lumpur, Malaysia: University of Malaya Press.

Tey, N. P., Lai, S. L., \& Noor Azina Ismail (2020). Demographic transition and socioeconomic development in Malaysia. University of Malaya Press, Kuala Lumpur.

Tey, N. P., Tan, B. A., \& Arshat, H. (1985). Multivariate areal analyses of neo-natal mortality in Peninsular Malaysia. Malaysian Journal of Reproductive Health, 3(1), 46-58.

World Bank (2017). Malaysia Economic Monitor - Data for Development,

World Bank Group (Global Knowledge \& Research Hub in Malaysia). Retrieved from https://www.worldbank.org/en/country/malaysia/publication/malaysiaeconomic-monitor-june-2017-data-for-development

Received: $11^{\text {th }}$ January 2021. Accepted: $12^{\text {th }}$ March 2021 